\title{
An Analysis of the Effectiveness of Sanctions as a Law Enforcement Tool in International Law: A Case Study of Zimbabwe from 2001
} to 2013

\author{
Cynthia Chipanga ${ }^{1}$, Torque Mude ${ }^{2}$ \\ ${ }^{1}$ International Studies, Midlands State University, Gweru, Zimbabwe \\ ${ }^{2}$ International Relations, Midlands State University, Gweru, Zimbabwe \\ Email: mudet@msu.ac.zw
}

Received 29 July 2015; accepted 18 October 2015; published 21 October 2015

Copyright (C 2015 by authors and Scientific Research Publishing Inc.

This work is licensed under the Creative Commons Attribution International License (CC BY). http://creativecommons.org/licenses/by/4.0/

\section{(c) (1) Open Access}

\begin{abstract}
The focus of this research is analysing the effectiveness of sanctions as a law enforcement tool in international law, a case study of Zimbabwe from 2001 to 2013 , to analyse the extent to which sanctions are effective in compelling the behaviour of the targeted ZANU PF elite. The conclusion drawn from this research was that sanctions were not effective in compelling the behaviour of the targets as they strengthened their undemocratic practises and human rights violations. Moreover, the lack of a comprehensive nature of sanctions led the targeted circumventing the restrictions, as there was room for other alternative options. In addition, sanctions ended up hurting the innocent civilians, thereby violating international law.
\end{abstract}

Keywords

Sanctions, Effectiveness, Zimbabwe, International Law, Law Enforcement

\section{Introduction}

International law is an instrument governing the behaviour of states and non state actors in the international system. The main function of international law is to ensure peace and security in the international community. International law consists of law enforcement tools that assist in the regulation of the behaviour of international actors. The use of force though not prohibited is usually not the desired way of regulating international actors' behavior; hence the use of sanctions is desired often to compel a state to adhere to the rules of international law. 
Unlike in the past where military warfare means were regarded as instruments of coercing actors to sustain behaviour that was in line with international law, ever since WW1, sanctions have been viewed as the alternative liberal approach to war.

Article 41 of the United Nations (UN) Charter stipulates that the Security Council (SC) may call upon member states to apply measures not involving the use of armed force in order to maintain or restore international peace and security (Charter of the United Nations). Sanctions are coercive diplomatic measures that are used by states and non state actors in international law to compel a state to change a certain behaviour or policy that violates the principles of international law. The post Cold era witnessed the use of sanctions against states rising at an exponential rate. This is tied to the fact that their growing popularity has avoided a World War from occurring as states now employ diplomatic coercive methods to confront matters of national interest and those threatening international peace and security.

Sanctions have been used to address a wide spectre of issues ranging from terrorism, nuclear proliferation of weapons, human rights violations and democracy only to mention but a few. International law has been the basis of the use of sanctions. Chingono et al. (2013: p. 307) purported that the objectives of sanctions included deterring a target from engaging in unlawful behaviour, compelling an offending state to dispose of or cease behaviour that the sanctioner considered wrongful, changing the target state's behaviour by subverting the incumbent wrong-doers, playing a punitive role or expressing a policy position symbolically to one's own public or to other states in the international system.

The efficacy of sanctions remains a contested issue in the international fora, with increasing protests for the careful designing and monitoring of sanctions in a bid to sustain the foundations of international law. Sanctions may aim at particular items like movement of persons, bar investments, or freeze international financial assets. Much has been written about sanctions and international law in various sanction regimes in the global arena such as those of Iran and Iraq but the case of Zimbabwe seems to have been left out. Henceforth, it is the central interest of this study to analyse the effectiveness of sanctions as a law enforcement tool in international law, the case of Zimbabwe from 2001 to 2013.

\section{Background to the Problem}

Zimbabwe (Rhodesia by then under the Smith regime) received sanctions from the UN in an effort to compel her to abandon the unjust and unfair Smith unilateralism against black majority. Twenty years later, the sanctions which were once used to get rid of the imperialist regime struck back again, this time on a democratic and sovereign state. Chingono (2010: p. 066) asserts that the period of 2000 to 2003 saw Zimbabwe receiving a wide range of sanctions from the European Union (EU), the United States (US), New Zealand and Australia. These sanctions ranged from targeted 'smart sanctions' to economic sanctions which were to ban travels, freeze assets of certain targeted individuals from the Zimbabwe African People's Union (ZANU PF) who were accused of human rights and democracy violations.

Chingono (2010: p. 67) argued that the reasons underlying Zimbabwe's bond of sanctions have been marred with controversy from both the perspective of the sanctioners and the sanctioned. The argument from ZANU PF is that these sanctions were not targeted "smart" sanctions but economic sanctions which destroyed the economy and hurt the innocent civilians. The contested fast track land reform programme is believed to be the bone of contention for the imposed sanctions from the ZANU PF perspective. In contrast the, EU and the US argue that the fast track land reform programme was inhuman and a breach of international law.

It is imperative from the onset to underscore that land is a major element in Zimbabwe's ecosocio and political developments. Tracing back down memory lane, the land question can be traced back to the settler occupation in 1890 which marked the commencement of the land dispossession of the majority black. The creation of the Gwaai and Shangaai reserves in 1893 dispossessed the blacks of fertile land and gave the fertile lands to the minority white. The following first and second Chimurenga wars were fought to gain among other rights - the right to land. The Lancaster House Conference in 1979 main focal point was the land question and today the imposed sanctions are also among other factors a result of the fast track land reform programme.

The sanctioners main argument to its sanctions was the lack of democratic norms carried out by the regime of Mugabe. The US in 2001 passed the Zimbabwe Democracy Recovery Act (ZIDERA) to ensure the transition to democracy and recover the economy of Zimbabwe (ZIDERA, 2001) stipulated US's support of the people of Zimbabwe in their struggle to effect peaceful, democratic change, achieve broad-based and equitable economic 
growth, and restore the rule of law. The US postulated that the government of Zimbabwe was unable to participate in the programs created by the International Monetary fund (IMF) and International Bank for Construction and Development (IBCD) to assist in the transformation and resuscitation of Zimbabwe's economy (ibid). Pursuing this further was the exclusion of the people of Zimbabwe from the economic and democratic benefits laid out by program donors, including the US due to economic mismanagement, undemocratic practices, and the costly deployment of troops to the Democratic Republic of the Congo (DRC) by the Zimbabwean government (ibid). Attached with this, was the economic mismanagement which was authenticated by the unbudgeted compensation of the war veterans in 1997 by the government which led to an economic crisis. In 2002 the US and the UK joined forces and its allies to impose sanctions on Zimbabwe. The denial of the Swedish head of the election monitoring team argued to be interference in Zimbabwe's internal affairs by ZANU PF followed. Accordingly, the EU accused the regime of Mugabe of electoral fraud in 2000 parliamentary and 2002 presidential elections. Consequently the EU imposed targeted sanctions on Mugabe and ZANU PF elite from travelling to Europe, freezing assets and bank accounts.

Hughes (2007: p. 323) asserts that since gaining independence in 1980, Zimbabweans have been Mugabe's passengers on a wild ride from hopes of postcolonial peace to a reality marked by violence and discord This is evidenced with by Operation Gukurahundi in the 1980s and continuing with a controversial "fast-track" landredistribution program which was followed by successive waves of trauma for the nation, including food riots in 1997 and 2003, an internationally fated presidential election in 2002, and, beginning in May 2005, a massive slumclearance "Operation Murambatsvina" and its ineffective follow-up re-housing plan entitled "Operation Garikai/ Hlalani Kuhle" (Hughes, 2007: p. 324). Also known as "Operation Tsunami", reflecting the havoc it wreaked on more than 700,000 people who lost their homes and sources of income and the 2.4 million others who felt its more indirect effects, Operation Murambatsvina is among other factors the origin of the imposition of sanctions against Zimbabwe Kuhle (Hughes, 2007: p. 326).

An equally significant aspect is the role of the opposition vibrant Movement for Democratic Change (MDC) which came to action in 1999 and barely after less than a year of its birth shook the dominant ZANU PF by garnering $47 \%$ of the parliamentary seats in the 2000 parliamentary elections. The MDC backed the sanctions on the economy and ZANU PF officials as a way to rectify the political situation and economic turmoil in Zimbabwe. Undoubtedly the calling of sanctions by the MDC was also to garner political mileage at the expense of the declining popularity of ZANU PF. The Australian government also followed suit by imposing targeted against government officials sanctions included travel bans to Australia, freezing of assets and bank accounts, coupled with this was the removal of the children of the ZANU PF elite in Australian education institutions due to the devastating political situation in Zimbabwe.

Sanctions against Zimbabwe were conflict-ridden as SC permanent members failed to reach a consensus. The period under study, as Chogugudza (2009) reiterates has seen the US, France and UK at the forefront, calling for the imposition of mandatory comprehensive UN sanctions against Zimbabwe, a move that has suffered dismally in the hands of Russia and China with the support of South Africa who consistently vetoed the successive calls for Zimbabwe Sanctions (2002). The west have argued that the imposition of the US sanctions was because of human rights abuses, white farm invasions, alleged election fraud, Operation Murambatsvina (clean up), harassment of opposition activists and lately, the alleged denial by Mugabe and ZANU PF to fully implement the provisions of the Global Political Agreement (GPA).

\section{Literature Review}

The popularity of discussions and debates surrounding the issue of the imposed sanctions on Zimbabwe continues to rise from the genesis of its imposition. Most proponents have largely dwelt upon the causes, nature and removal of the imposed sanctions on Zimbabwe. Yet little has been written about the efficacy of sanctions as law enforcement tool in international law. It is striking to the researcher's attention that not much has been written on the efficacy of sanctions in the context of international law in Zimbabwe.

The works of Chingono, Hove, \& Danda (2013) specialised on how globalisation influenced the effectiveness of sanctions exploring the extent to which globalisation nullified the efficacy of sanctions. Chingono et al. (2013: p. 307) views globalisation as rendering the economic sanctions ineffective because no country is an "island" and the phenomenon of interdependence enables countries to "survive" through trade, cooperation, multi-lateral and bilateral loans or credits. They argue that sanctions work in an air tight global environment when the sanc- 
tioned are isolated. Emphasis is also drawn from China's role in providing countries with alternative trading partners rendering the utility of sanctions ineffective Chingono et al. (2013: p. 308).

It is factual that globalisation affects the effectiveness of sanctions but it would be blindness to leave behind the fact that the international system is a brutal arena. States prioritise survival more than cooperation. Accordingly power politics is bound to affect the efficacy of sanctions. This is evidenced by the US's strategic interest in Zimbabwe's land issue on one hand and China's interest in Zimbabwe on the other hand which poses as a need for the economic giants to control resources in Zimbabwe. The authors dwelt much on interdependence as a major effect of the effectiveness of sanctions ignoring the role of power politics. In addition, they discount the role played by international law as an element of globalisation in the efficacy of sanctions.

Paul \& Akhtar (1998) blame the failure of the effectiveness of sanctions on international law and laments that sanctions hurt the innocent other than the targeted individuals. This is due to the fact that international law has developed no principles on which sanctions can be based owing to the lack of the definition of the "determination of an aggressive act" (ibid). It is to the researchers' deliberation that even though international law is to blame for the lack of effectiveness of sanctions, the writer dwelt much on UN sanctions yet they are also unilateral sanctions. To add insult to injury, the writer gives a general analysis of the effectiveness and impacts of sanctions and does not specifically analyse the Zimbabwean case. Moreover there seems to be a tendency by scholars dwelling much on the effects or rather the impact of sanctions yet one need to know from the onset the underlying reasons for both the failure and success of sanctions. It is thus the central interest of this research to fill the missing gap on the subject of sanctions.

Smith-Höhn (2010: p. 1) discusses the relevance and effectiveness of sanctions and the potential likelihood of the lifting of sanctions in a new political environment brought in by the Government of National Unity (GNU) Smith-Höhn (2010: p. 4) puts the failure of the efficacy of sanctions on the inconsistencies of their implementation and selective nature and loopholes in travel bans. Without doubt sanctions have served as a scapegoat of Mugabe's problems. It is paramount for one to applaud the author for analyzing the effectiveness of sanctions and bringing up relevant factors underlining the failure of the effectiveness of sanctions. Nevertheless, the author seems to dwell much on the period during the Global Political Agreement overlooking the period prior the formation of the GNU.

Tungwarara (2011) highlights the causes and events of the imposed sanctions, does not give an analysis of the effectiveness of sanctions but rather gives a description of the events that took place due to both the failure and success of sanctions. Moreover, the dwells much on the GNU, and leaves an open question subject to debate"whether sanctions have strengthened the prospects of democratisation or simply made life worse for ordinary citizens" (effectiveness) (Tungwarara, 2011: p. 112). It is thus the central interest of this research to analyse how and to what extent sanctions have led to a behavioural change of the targeted.

Mbanje \& Mahuku (2011: p. 1) analyse the negative impact of sanction. The authors argue that the Look East Policy has helped to stabilise Zimbabwe's heavily sanctioned economy thus alleviating collapse of a once thriving and vibrant economy. It is important to note that they dwell much on the impacts of EU sanctions overlooking those by US and Australia. They limit their research to the effects of sanctions on agriculture, health and education sectors and hardly touch on the issue of the efficacy of sanctions. This research however seeks to dwell on the efficacy of the imposed EU, US and Australia sanctions

Grebe (2010: p. 3) examines the EU and US's targeted sanctions against the Zimbabwean government arguing that the sanctions are not effective and have resulted in the failure to achieve their political objectives' The author owes the inefficacy of sanctions to the wide varying of violations of the travel and financial restrictions and addresses the issue surrounding the outcome of targeted sanctions against authoritarian governments. Despite the research holding much water, the author does not mention the efficacy of sanctions in the context of international law. Moreover, they are other factors owing to the inefficacy of sanctions such as those of globalisation which were touched upon by Chingono, Hove, \& Danda (2013) and which this research will dwell upon.

Masaka (2012: p. 49) examines the seemingly paradoxical sanctions discourse within Zimbabwe's political establishment where targeted sanctions are seen both as an impediment not only to economic growth but also to political stability and, at the same time, as a convenient tool to garner political mileage by both ZANU PF and MDC formations. While the MDC factions see sanctions on Zimbabwe as precisely targeted sanctions that are meant to keep in check members and sympathizers of the former ruling party, ZANU PF, as well as institutions, and business organizations that are perceived to be, among other things, encouraging the violation of human and property rights, promotion of undemocratic tendencies, lack of rule of law, and suppression of the press and 
freedom of speech and association, ZANU PF tends to see them as a Western strategy to effect regime change by weakening ZANU PF and, at the same time, strengthening the Western-backed MDC via such unorthodox means (ibid).

The debate over the origins, nature and impact of the "sanctions" imposed by the US and EU on President Robert Mugabe and individuals in the inner-circles of his ruling party, ZANU PF, for allegedly contributing to the undermining of democratic processes and institutions in the country by electoral fraud, human rights abuses and bad governance. He further ascertains that ZANU PF also accuses the MDC for calling for the imposition and renewal of the US and EU "sanctions" in order to gain political mileage by bringing economic hardships so that people would remove it from power through the ballot box or violence (ibid). Far from being a tool to force ZANU PF to reform, the "sanctions" have been seen to be crippling the economy and hurting the innocent civilians and that the "sanctions" made the country's political crisis more complex and had the inadvertent effect of providing ZANU PF with ready-made excuses for the country's economic failure and its refusal to implement democratic reforms (ibid). The author also discusses the debates over the legality of the imposed sanctions on Zimbabwe. Nonetheless, the researcher only focuses on the period from 2001 to 2010 . This research, however, seeks to stretch the period up to 2013.

\section{Theoretical Framework}

The amount of intellectual and theoretical artillery that has been used in theorising the effectiveness of sanctions is wide and varied. This research will dwell much on the traditional or punishment theory. Lektzian \& Souva (2007: p. 850) assert that traditional theory is based on a simple hypothesis which is; cause enough pain and the target will change its policy, in the same manner, if economic sanctions are severe enough they will harm a target's country's economy (ibid). This will lead to political disintegration brought about by the unwillingness of the population in the target country to suffer economically because of an internationally unpopular policy. As a result, increased pressure is placed on a target government to comply with the sanctions demand hence the more value deprivation, the more political disintegration (ibid).

\section{Concept of Sanctions}

Chingono, Hove, \& Danda (2013: p. 307) maintain that sanctions are a foreign policy tool used by states or international organizations to persuade a particular government or group of governments to change their policy by restricting trade, investment or other commercial activity. Hove (2012: p. 72) articulates that sanctions are a penalty imposed to ensure international law whose major aim is to punish the law breaker so as to avoid him from attaining his objectives and to change the rule breaker's policy. As such one can safely note that sanctions are in some instances a form of punishment to a target state in an effort to compel it to change certain unacceptable behaviour. However, the EU (2008) does not view sanctions as punishment per se but as an "instrument of a diplomatic or economic nature which seek to bring about a change in activities or policies such as violations of international law or human rights, or policies that do not respect the rule of law or democratic principles". Paul \& Akhtar (1998) assert that Ambassador Legwaila (1995) in a January 1995 Council debate emphasised that sanctions are meant to bring about a "change of behaviour", and are not supposed to be "punishment or retribution".

Sanctions can be unilateral and multilateral in nature. Prof. Mohamad in a presentation articulated that unilateral sanctions are imposed by a single state which resorts to unilateral sanctions as a tool of foreign policy with an objective to transform the targeted country's behaviour (Symposium on Unilateral Sanctions and International Law: Views on Legitimacy and Consequences, 2013: p. 9). Multilateral sanctions are imposed by a group of states such as the UN.

The term "sanctions" has been an issue of debate among schools of thought with some interchangeably using the term with "counter measures" and "restrictive measures". Dr. Tzanakopoulos in a presentation asserted that like states, international organisations may also implement unilateral sanctions against states or other international organisations with the EU being particularly active in this respect behaviour (Symposium on Unilateral Sanctions and International Law: Views on Legitimacy and Consequence, 2013: p. 9). Furthermore the term "sanctions" is problematic in the sense that International Law Commission (ILC) has used the term "countermeasures" to refer to unilateral measures by states in response to illegal conduct by other States, while reserving the term "sanctions" to collective measures taken by international organisations, most prominently the UN (ibid). 
Despite the differing in terminology it is important to note that the terms have almost everything in common in respect to their application and adoption with the exception of their difference in terms.

It is widely accepted that sanctions take the form of travel restrictions, foreign aid reductions and cut-offs, trade bans, asset freezes, tariff increases, revocation of most favoured nation, trade status, negative votes in international financial institutions, removal of diplomatic relations. Sanctions can be economic or targeted. Chingono, Hove, \& Danda (2013: p. 308) argue that whilst sanctions have a myriad of objectives depending on which actor is sending them, unilaterally or multilaterally, one lucid objective among these is sanctions' bid to isolate the respective state practising objectionable policies. Chingono, Hove, \& Danda (2013: p. 307) further reiterate that their objectives include deterring a target from engaging in wrongful behaviour, compelling an offending state to abandon or cease behaviour that the sanctioner considers wrongful, alter the target state's behaviour by subverting the incumbent wrong-doers, play a punitive role or to express a policy position symbolically to one's own public or to other states in the international system.

Eriksson (2007: p. 7) presumes that targeted sanctions, often termed "smart sanctions", are usually targeted at a small circle within the ruling elite of a given country, and were developed as an alternative to comprehensive sanctions that had proven to have a more devastating impact on the broader population than on those whose behaviour the sanctions had intended to influence. The author further argues that the rationale behind the targeted measures is to pressure key decision-makers considered to bear direct or indirect responsibility for a political or economic crisis in a particular regime with the objective of persuading or compelling them to change their behaviour (ibid).

Economic sanctions pressurize the intended state into compliance through intentional incapacitation of the economy. Comprehensive sanctions are full restrictive measures, including trade and financial sanctions. Sanctions have been constantly used due to their low costs as compared to war. This also grew from President's Woodrow Wilson recommendation that: "A nation that is boycotted is a nation that is in sight of surrender. Apply this economic, peaceful, silent, deadly remedy and there will be no need for force. It is a terrible remedy. It does not cost a life outside the nation boycotted, but it brings pressure upon that nation which, in my judgement, no modern nation could resist" (Chogugudza, 2009).

\subsection{History of Sanctions}

Historically sanctions can be traced back to $435 \mathrm{BC}$ in Athens when Pericles, a statesman in Athens ordered all trade banned between the Athenian Empire and Megra, a city-state that had sided with Sparta, Athens' enemy (Thucydides, 1972: pp. 118-123). He anticipated to sending a message that, short of going to war, Athens would punish anyone who challenged her authority, ultimately the sanctions lead to a thirty-year war (ibid). Sanctions were then implemented by Napoleon in the Continental System in 1806 and also by Thomas Jefferson in the Embargo Act of 1807. Elliott \& Hufbauer (2002) maintain that that the League of Nations imposed or threatened to impose economic sanctions only four times in the twenties and thirties, twice successfully but the league faded from history when its ineffectual response failed to deter Mussolini's conquest of Ethiopia in 1935 and 1936.

The Cold War ushered the world into a new phase which saw the U.S.S.R. and the United States emerging as superpowers. Smith (2006) argued that both the superpowers tried to gain a competitive edge over each other by cooperating with corrupt leaders henceforth deviating from the use of sanctions and inherently making the use of sanctions an ineffective tool of altering state behaviour. The UN only imposed sanctions against Rhodesia (1968) and South Africa (1977) before the fall of the Berlin Wall. The period after the fall of the Berlin Wall saw the increase of the use of sanctions by international organisations and mostly by the undisputed champion of unilateral sanctions, the US.

The post Cold War era also saw several sanctions being adopted by the UN Security Council against a number of countries, these include the Taliban (1999), UNITA of Angola (1993), Haiti (1993), Iraq (1990), Serbia(1994), Somalia, (1992) Sudan (1996), Libya (1992), Rwanda (1994), Yugoslavia (1992), Liberia (1994), Sierra Leone (1997), the Federal Republic of Yugoslavia (1998), Iran 1979 only to mention but just a few. Smith (2006) asserts that their violations included external and internal aggression, support of terrorism, and suppression of democracy. The US' military might, economic prowess has given it greater capability to impose unilateral sanctions, giving greater authority to its unilateral sanctions which was and is due to its economic prowess. It would be befitting to place the US as the only nation adopting unilateral sanctions, it is imperative to take into 
consideration that other states have also been adopting their single-nation bans and proposals with the European Union sponsoring their own brand of sanctions.

\subsection{Legal Framework of Sanctions in International Law}

The issue of sanctions emanates from the UN Charter which has been the source of the legality of sanctions in international law. Chapter VII Article 41 of the UN Charter stipulates that:

"The Security Council may decide what measures not involving the use of armed force are to be employed to give effect to its decisions, and it may call upon the Members of the United Nations to apply such measures. These may include complete or partial interruption of economic relations and of rail, sea, air, postal, telegraphic, radio, and other means of communication, and the severance of diplomatic relations (Charter of the United Nations)".

In accordance with Article 39 the SC shall: “...determine the existence of any threat to the peace, breach of the peace, or act of aggression and shall make recommendations, or decide what measures shall be taken in accordance with Articles 41 and 42, to maintain or restore international peace and security" (ibid).

It is important to take note that Article 41 does not use the term "sanctions" but rather refers them to "measures" that can be used for maintaining international peace and security. These measures have been termed as sanctions in the long run. After ascertaining the existence of a "existence of any threat to the peace, breach of the peace, or act of aggression", prior to getting to apply the collective security measures stipulated by the Chapter VII of the Charter, the SC may invite the interested parties to accept the temporary measures that it considers as being necessary. Whilst in the absence of a corresponding response from the state whose actions represent a threat against peace, an act of aggression, the SC may take a series of political, economical or military measures against the state.

The legality of sanctions in international law is a contested issue among various schools of thought. It is imperative to draw from the works of Kôchler (1992: p. 2) in which he argues that it remains unquestionable that sanctions are permitted by law as specific counter measures to the violations of international law and that, in the event of such a violation, contractual obligations to the Iaw-breaking state which otherwise apply are invalidated. The lawfulness of sanctions in international law is to a greater extent a widely accepted notion, contrasting perceptions seem only to rise in the circumstances under which these measures are undertaken.

Trocan (2009) asserts if an unlawful act is done by a state against another state, the victim-state ascertains and tests the act's illicit character, it may begin to apply sanctions. A state may thus apply sanctions to a state that is a threat to peace to her. If a jus cogens law, from the international law is encroached, it is every state's interest, not only the victim-state's, to undertake the measures that are imposed so that the imperative law be complied with (ibid). This implies that the responsibility of imposing sanctions against a state which infringes international law does not lie only on the directly affected state but by other states too in an effort to uphold the rule of international law. As a result, sanctions can be applied by states, the UN, international organizations, but only and unless they are authorised by international law. This argument stems out the legality of both unilateral and multilateral sanctions.

The credibility of unilateral sanctions is disputed by Prof. Dr. Mohamad whom while in a presentation argued that unilateral sanctions are prohibited under international law as the Charter of the UN addresses only collective "measures" (Symposium on Unilateral Sanctions and International Law: Views on Legitimacy and Consequences, 2013: p. 9). This is due to the fact that sanctions are imposed by a state through application of its national legislation, which are prima facie extra-territorial in character and against the customary principles of jurisdiction under international law (ibid). The argument is sustained by the fact that all national legislations are bound to be territorial in nature as enshrined in international law. It is paramount to take cogniscance of the fact that that the extra territoriality nature of sanctions makes them unlawful in international law as they violate the legal equality and territorial sovereignty of states.

Abadi (n.d: p. 4) maintains that unilateral sanctions are illicit in international law as states are independent and legally equal under international law, no state can exercise its authority over the territory of other state without the latter's consent. Accordingly, the International Court of Justice (ICJ) established the basic principles of jurisdiction in the Lotus case: "Now the first and foremost restriction imposed by international law upon a state is that-failing the existence of a permissive rule of the contrary-it may not exercise its power in any form in the territory of another State" (Abadi, n.d: pp. 4-5). 
In the same manner, jurisdiction is without doubt territorial, it cannot be undertaken by a state outside its territory with the exception of being guided by rule or norm derived from the sources of international law. Henceforth unilateral sanctions are only legal when they are guided by norms from international law. Art.2 (1) of the Charter of the UN states that: "the Organization is based on the principle of sovereign equality of all its members". It is from this stand point that the recognition of the need of respecting the equality, independence and territorial integrity of states is established from. An equally significant aspect of international law is the right to self-determination (Charter of the United Nations). By the same token it is recognised that one of the fundamentals of sovereignty is its exercise within in territorial boundaries.

Humanitarian exceptions are universally accepted to be taken into consideration when imposing sanctions. This is because enforcing the fundamental objectives of international law should not end up violating the foundations of international law.

\section{Rationale for Imposition of Sanctions on Zimbabwe}

ZANU PF has continually insisted that the west imposed sanctions against Zimbabwe are as a result of EU and US resentment of the land reform programme which resulted in loss of farms by white farmers. The government of Zimbabwe argues that the move was done to reprimand the Zimbabweans of their rightful land ownership. Land was attained through the Land Acquisition Act (LAA) which targeted foreign owned land, abandoned and under-utilised land, and land under multiple ownership. Chingono (2010: p. 067) argues that it is at this point, that, the Zimbabwean government fell out of favour of Western support on the pretext that they had allowed a perpetration of human rights abuses and disrespect for property ownership rights. The West went on to accuse the Zimbabwean government of being undemocratic and not upholding the proper principles of good governance (ibid).

An equally important aspect underlying the reasons behind sanctions against Zimbabwe is Zimbabwe's entrance into the DRC War of Independence. Mashingaidze (2006: p. 58) puts it that, in 1998 Zimbabwe, together with Angola and Namibia deployed troops to the DRC to prop up the Laurent Kabila regime, which was under immense threat from Ugandan, and Rwandan backed rebels and at its height in 2000, the DRC military ventures drained at least US \$1 million per day, from the Zimbabwean fiscus. ZANU PF however argues the action was in line with the SADC principles. This war was condemned by the sanctioners as it deviated finances for developmental purposes to Mugabe's political ambitions. To add insult to injury, the Mugabe regime compensated war veterans with unbudgeted money which led to an economic crisis. Coupled with this was the heave of corruption undertaken by the Zanu elite at the expense of the ordinary citizens.

Human rights violations by the Mugabe regime are also a major reason behind the imposition of sanctions against Zimbabwe. Foreign critics have said the ruling ZANU PF rigged parliamentary elections in 2000 and the 2002 presidential poll, and accuse the government of widespread human rights abuses (EU Renews Targeted Sanctions against Mugabe, 2013). ZANU PF is accused of political intimidation, violence against opposition parties, human rights abuses and deteriorating democratic standards. Moreover, the Mugabe regime carried out a clean-up campaign in May 2005 which continued up to 2006 and resulted in the displacement of more than 1 million people. The operation was condemned by the sanctioners for violating human rights for the reason that people were left homeless and deprived of the right to shelter. The follow up campaign "Operation Garikayi/ Hlalani Kuhle" which was meant to deal with the crisis proved a failure thereby undermining of rule of law.

The other reasons for the sanctions were poor governance and the repression of lack of freedom of speech and association. The government of Zimbabwe consistently argued that it was the one that initiated democracy into Zimbabwe since gaining independence in 1980. The EU (2002: p. 5) "expressed its serious concern about the situation in Zimbabwe, in particular the recent escalations of violence and intimidation of political opponents and the harassments of the independent press... The Council has assessed that the Government of Zimbabwe continues to engage in serious violations of human rights and of the freedom of opinion, of association and of peaceful assembly..."

\subsection{Nature of Sanctions against Zimbabwe}

The nature of sanctions imposed in Zimbabwe is one subject of debate that has grown exponetionally. The sanctioners on one hand argue that the sanctions they imposed on Zimbabwe were targeted while on the other hand the sanctionees lament that these sanctions were not targeted but economic sanctions meant to derail the econo- 
my of Zimbabwe. Chingono (2010: p. 070) is of the view that the Government of Zimbabwe argues that the US sanctions imposed on Zimbabwe are comprehensive and economic in nature since they have caused adverse economic costs both on the economy and the masses. Their argument is strongly supported and revolves around the US enactment of the ZIDERA of 2001 specifically contained in Section 4c, titled "Multilateral Financial Restrictions" Until the President makes the certification described in subsection (d) ... the Secretary of the treasury executive director to each of the international financial institutions to oppose or vote against:

i) An extension by the respective institutions of any loan, credit or guarantee to the Government of Zimbabwe or

ii) Any cancellation or reduction of indebtedness owed by the Government of Zimbabwe to the United States or any international financial institution (ibid).

This act disapproved the Government of Zimbabwe of financial aid from the Brettonwoods institutions and the AFDB without the endorsement of the US president. From the time when ZIDERA came into action any loan application made to the IMF, WB or AFDB was either disillusioned by the US through its influence over the International Financial Institutions (IFIs) or through its vote. Zimbabwe voting rights were suspended in the IMF in 2003. Ironically The US had imposed economic sanctions on Zimbabwe. Figure 1 shows the decline of aid from IFIs ever since the period of sanctions, the period prior sanctions, and aid was constant.

ZANU PF expressed anger over sanctions on several occasions. The then Information Minister, Jonathan Moyo contended, "It is very clear that what we are now dealing with is organised economic terrorism whose aim is clear and is to unseat a legitimately elected government which has decided to defend its national independence and national sovereignty... it is a shame for such a mighty region, for a whole continent to descend on a small country in such a personalised manner" (The CNN, 2002). The sentiments expressed embody the anger of the ZANU PF over the sanctions imposed on the government officials in an effort to change the regime of Zimbabwe. However, the EU commissioner of external affairs Chris Patten told CNN that the sanctions were aimed at specific individuals, rather than the (Zimbabwean) people themselves (ibid).

Smith-Hohn (2010: p. 2) asserts that restrictions on arms and military-related trade were the first in a series of steps taken by the UK, the US and EU following international dissatisfaction with developments in Zimbabwe. The goal was to diminish the aptitude of the regime of Mugabe to oppress its own people. The UK in 1997 also denied delivering vehicles to the Zimbabwean police. In 2000 and 2003, the US imposed a ban on the transfer of defence goods and services. The UK banned selected government officials from travelling to the UK and also froze their assets. Basing on the ZIDERA the US also imposed targeted travel bans and asset freezes on more than 200 Zimbabwean businesses and individuals. Switzerland and Australia also placed travel restrictions and asset freezes on the ZANU PF elite. Australia and used also put travel bans on the adult children of the targeted individuals. The 2002 condemned elections resulted in the Commonwealth suspending Zimbabwe for a year which subsequently led to the withdrawal of Zimbabwe from the body. Smith-Hohn (2010: p. 2) asserts that in 2000, the UK reduced its bilateral aid by as much as one-third of its previous sum and in 2002 the EU restricted development assistance to Zimbabwe to emergency humanitarian aid and social projects. New Zealand and Australia pursued further to put travel bans on the adult children of the targeted individuals.



Figure 1. IFIs disbursements in \$ US to Zimbabwe. Source: Gono (2007) amended by researcher. 
Gono (2007: p. 4) also articulates of undeclared sanctions in which define them as not explicitly announced but implied from the actions of the perpetrating nations, for example, some Non-Governmental Organizations (NGOs) have moved their operations out of Zimbabwe, since the enactment of the ZIDERA of 2001.

\subsection{Legality of the Imposed Sanctions on Zimbabwe}

The legality of the Zimbabwe imposed sanctions remains a contested issue, with the ZANU PF on one hand dismissing the imposed sanctions as illegal and a violation of international law whilst on the other hand the sanctioners and the MDC-T insisting their legal nature which is in line with international law.

ZANU PF argues that the sanctions are illegitimate for the reason that they were imposed outside ambit and mandate of the UN referring to Article 2 subsection (3) of the UN Charter which requires states to settle their disputes amicably first by resorting to conciliation, arbitration, negotiation (Parliamentary Debates, 2006: p. 66). Correspondingly ZANU PF argues that the SC is the only organ in the world that has the mandate, power and authority to supervise, oversee international relations as enshrined by Chapter VII (Parliamentary Debates, 2006: p. 60). The sentiment expressed in this line, embodies the view that leaves one to admit that the sanctions imposed on Zimbabwe were unlawful. An equally significant aspect in this manner is President's Robert Mugabe's attacking and exposing of the US, UK and EU at international forums for imposing illegal sanctions against Zimbabwe which are in violation of international law. This is evidenced by Mugabe lashing out of the US and Britain at the General Assembly meeting, "Our small and peaceful country is threatened daily by covetous and bigoted big powers whose hunger for domination and control of other nations and their resources knows no bounds. Shame, shame, shame to the United States of America, Shame, shame, shame to Britain and its allies" (Full Text: Mugabe's Speech to the 68th Session of UN General Assembly, 2013).

The sentiment expressed in the citation, embodies the view that big powers imposed sanctions on Zimbabwe in an attempt to serve their national interests by using their prowess over a smaller state. Association of Zimbabwe Journalists (in Chingono 2009: p. 066) reiterate that the Mugabe regime perceives the use of economic sanctions as an illegal tool meant to destabilize the internal political interactions of the country (particularly the land reform exercise) and a serious infringement of the principle of non-interference and sovereignty. In the face of such criticism, the sanctioners, the two MDC formations (MDC-T and MDC-N) and international west backed humanitarian organisations have responded by justifying the imposition of sanctions in a number of ways. International Crisis Group (ICG) (2012: p. 2) maintains that the sanctions on Zimbabwe were introduced in reaction to political violence, human rights and rule of law violations, on top of deteriorating democratic standards that followed the violent election processes in 2000 and 2002. Additionally, sanctions were neither comprehensive nor illicit, as often argued by ZANU-PF as they embrace a set of "restrictive measures" introduced and tailored over the last decade by the US, EU and other countries targeting specific individuals and entities (ibid). In a way, sanctions were not meant to harm the general populace or violate the basic human rights of the people of Zimbabwe as argued by ZANU PF but were targeted on certain individuals. Chogugudza (2009) asserts that the sanctioners justify sanctions due to poor human rights record, whiter farmer investigations, alleged election rigging, Operation Murambatsvina (clean up), persecution of opposition activists, the alleged refusal by Mugabe and ZANU-PF to fully execute the provisions of the Global Political Agreement (GPA). Pasirayi (2009) argues that sanctions imposed on the political elite were legal because they were imposed on a coterie of corrupt officials, sponsors and perpetrators of human rights abuses in Zimbabwe.

\subsection{The Effectiveness of Sanctions Imposed On Zimbabwe}

This section analyses the effectiveness of sanctions using evidence from collected from various secondary sources. This section also tries to analyse the extent to which the objectives of the sanctioners were met, in other words, it tries to measure the extent to which sanctions were effective in changing the behaviour of the targeted individuals. In a way, the section analyses the extent to how the sanctions brought about a positive change and how they were an effective law enforcement tool of international law.

It is imperative to analyse the extent to which travel restrictions were effective in changing the behaviour of the targeted. Without doubt, the travel ban was a major impediment to the targeted as they could no longer go to the destinations of their choices unlike the period prior the imposition of sanctions. The denial of visas was a key inconvenience to those who had personal and business endeavours in the countries which they been denied entry into. In spite of these claims, the travel bans were not clearly defined resulting in the their failure to exert so much needed pressure to compel the behaviour of the targeted ZANU PF elite. 
Smith-Hohn (2010: p. 4) emphasises that underscoring this dilemma is the fact that the travel restrictions apply only to certain countries and allow travel exemptions for participation in meetings coordinated by international organisations. Targeted individuals can therefore easily find ways to circumvent the ban-either by travelling to (and shopping in) countries that have not imposed such restrictions, or by attending international conferences or humanitarian events while at the same time pursuing their private interests in whichever countries they visit (ibid). The lack of lucidity on the limitations of the travel ban and the inherent loopholes enabled individuals to outwit the ban thereby culminating a negative effect on the efficacy of the travel restriction. Despite the restriction, President Mugabe and other government officials were still able to attend various international summits thereby exposing the lack of consistency of the travel restrictions

Smith-Hohn (2010: p. 4) asserts that in May 2002, Mugabe was received at the UN offices in New York on a Libyan airlines flight via Paris. The inconsistency of the travel ban also allowed Mugabe to attend Pope John Paul II funeral mass in 2005 in the Vatican City, to Rome for the World Food summit, and also to travel to Copenhagen in 2009 for the climate talks. ZANU PF officials' opportunities deemed to be impossible to prevent, for instance Gideon Gono, the Reserve Bank Governor and Herbert Murerwa, the former Finance Minister travelled to Washington DC in 2005 in which they attended an IMF Executive Board meeting. The ICG (in SmithHöhn, 2012: pp. 4-5) observed that in August 2002, only weeks after Police Chief Augustine Chihuri was placed on the EU's travel ban list, he travelled to Lyon to attend an Interpol meeting. Undoubtedly the travel bans hardly avoided ZANU PF officials from their trips around Europe, US and Australia but merely complicated and embarrassed their processes. Sims, Masamvu, \& Mirell (2010: p. 13) assert that Australia and New Zealand were the only countries that extended travel restrictions to adult children of ZANU PF officials and their allies. Additionally, in other countries, targeted individuals circumvented the ban by using their adult children who are spread across Europe and the USA to conduct business on their behalf (ibid). From this viewpoint, one can argue that the travel restrictions were not effective in putting pressure on the targeted government officials as they could either use their adult children to carry out their businesses in other countries that had not put travel bans on their adult children.

Pursuing this further is how the asset freezes managed to compel the behaviour of the targeted individuals. Portela in (ICG, 2012: p. 5) argues that freezes on assets were announced months before they were implemented, affording ample opportunity to move money and valuables. This leaves one to reach to the point that asset freezes were inconsistent, allowing the targeted to shift their treasures hence being ineffective. By August 2005 information from the EU was that assets worth $€ 825,000$ had been seized from the government by EU.

UK House of Lords (in Sims et al., 2010: p. 14) reiterate that the UK on its own had managed to freeze a paltry $£ 160,000$ by 2006; an amount so small that even the House of Lords Select Committee on Economic Affairs conceded that both in absolute terms and relative to the probable resources of the targets it is doubtful whether asset freezes are effective as a means of inhibiting changing the behaviour of those who are targeted. It is thus imperative to take into consideration that the amount of money that was froze of assets belonging to the targeted ZANU PF elites was insignificant to compel the behaviour of the targeted.

The arms embargoes were undermined by a lack of an international comprehensive arms embargo. Sims et al. (2010: p. 11) observed that despite embargoes placed by some in the West, Zimbabwe's defence ministry remained inextricably linked to arms manufacturers within Europe and the US. An International Peace Information Service Report identified weapons and weapons part transfers occurring within Montenegro (not within the EU) and the US (ibid) Illegal arms trafficking flourished through porous borders between Zimbabwe and its neighbouring countries. Johnson-Thomas \& Danssaert (2009) assert that in December 2008 the United Nations Security Council's Group of Experts on the DRC reported several ammunition deliveries of approximately 53 tons of ammunition to the regime of Zimbabwe. On many occasions Zimbabwe received arms from China thereby busting the arms embargo. The lack of an internationally comprehensive arms embargo resulted in the failure of the arms embargo to achieve its objectives.

Regardless of the pressure sanctions exerted on the government officials the contested and illegal (sanctioners view) fast track land reform was still in place. Farm invasions persisted targeting white commercial farmers in the land distribution despite their criticism from the west. These farm invasions which were in violation of property rights and international law derailed potential foreign investment. According to the Commercial Farmers Union (CFU), 152 of the 300 commercial farms that were still in operation were now being targeted for eviction (Zim Farm Invasions Keep Investors away, 2010). According to Civil Society Monitoring Mechanism (CISOMM) (2010: p. 18), the CFU rounded on the inclusive government, slamming the troubled administration's failure to stop a few extremists from openly threatening, physically attacking and illegally evicting com- 
mercial farmers and their workers.

The government efforts of protecting farmers whose farms were protected under government bilateral pacts were feeble. A notable example is the clash between the government of Zimbabwe and that of Germany over the violent grabbing of farms from German citizens by ZANU PF in which whose properties were protected by a bilateral agreement between the two countries. Consequently, the Harare Germany embassy wrote to the government of Zimbabwe protesting against the continued violations of their bilateral agreement arguing that this would hamper the county receiving financial aid from the Berlin. CISSOM (2010: p. 18) denotes that, the letter to the foreign affairs Minister Simbarashe Mbengengwi identified the properties occupied as Makandi Tea and Coffee (Private) Limited, Border Timbers Limited both in Manicaland province and Forester Estate (Private) limited in Mashonaland Central. According to CISSOM (2010: p. 19), part of the letter included this citation "The German Embassy notes with great concern that property rights of German nationals and their investments in Zimbabwe are being put under threat, in clear violation of international law".

The CFU continuously blamed the police for failing to uphold the rule of law of protecting farmers from violence, intimidation and extra judicial evictions initiated by ZANU PF. The CFU claims that senior ZANU PF officials led by former Land Reform and State Security Minister Didymus Mutasa threatened white commercial farmer Gavin Woest with death telling him he had minutes to vacant his property, responding to the claims, Mutasa said: These white people create stories. I have not gone to America or Britain for land. I get my land in Zimbabwe which is my country. What is wrong with that? (Mail and Guardian, 10 January 2010).

This citation embodies the view that, despite the sanctions, ZANU PF still saw no immoral in its violent acquisitions of land. At this juncture, it is plausible for one to argue that the sanctions were not effective in seizing the land grabbing exercise as continued land grabbing continued to exist. ZANU PF showed no signs of turning back from their land exercise as they argued that they were the rightful owners of the land. To add insult to injury, President Mugabe on several occasions encouraged the people of Zimbabwe to 'jealously guard' the inheritance from their hard owned independence referring to the natural resources. President Mugabe told his guests at his $85^{\text {th }}$ birthday festival "the few remaining white farmers should quickly vacate their farms, as they have no place there..." I am still in control and hold executive authority. Mugabe had seemingly forgotten his power sharing agreement with Prime Minister Morgan Tsvangirai by then which included an end to the ending of violent land grabbing. In the same manner the non withdrawal of ZANU PF from the land seizures also meant ZANU PF's dismissal of the SADC regional tribunal ruling in 2008 that ruled that the land reform programme was in violation of international law.

Nyamutata (2013) reiterates that in its manifesto "taking back the economy", indigenise, empower and develop and create employment, "ZANU PF has claimed the west's 'illegal' economic sanction have cost the country at least $\$ 42$ billion and Zimbabwe lost donor support amounting to approximately $\$ 36$ million annually, $\$ 79$ mil in loans from the IMF, WB and African AFDB, commercial loans of \$431 million and GDP reduction of 3.4 billion. It is paramount to note that ZANU PF made blunders before the period under study that resulted in the collapse of the economy. All the same, sanctions have been used by the Mugabe regime to garner party support, campaigning against sanctions as a tool of Western neo-colonialism. Smith-Hohn (2010: p. 5) asserts that Mugabe's manipulative use of terminology by describing smart sanctions as illegal has meant that instead of pressuring Mugabe and his allies, these measures have been taken hostage and are often used as a scapegoat, with the Mugabe government publicly blaming them for the country's economic decline. He has not spared any opportunity to denounce the targeted sanctions as serving the cause of the imperialists and colonialists, portraying himself as a hero of the masses (ibid). In spite of the sanctions compelling the behaviour of the government officials, the sanctions were in essence transformed into political capital used to culminate nationalistic tendencies against the west giving political mileage for the infamous ZANU PF. One can therefore reach to the point that sanctions were not effective in changing the behaviour of the ZANU PF but gave the targeted a vantage ground to unravel their losing popularity in so doing stabilising their position in the political arena

ZANU PF has time and again argued that sanctions were in violation of the principle of non intervention and sovereignty. However, it is noteworthy to take into account that Zimbabwe is a sovereign country and inherently makes it the core influencer of the of the country's economic performance. The economic crisis started way before sanctions were imposed. They were no sanctions in 1997 when the Zimbabwean dollar lost value by more than $75 \%$ against the US dollar on "Black Friday" the $14^{\text {th }}$ of November 1997. However, it was because of the government's compensation of war veterans with unbudgeted money and its entrance into the costly DRC war of independence. 
A principal hindrance on the efficacy of sanctions on Zimbabwe has been the amount of support that the Mugabe administration has received from the AU and SADC and other states. The support rendered to Mugabe has positioned Mugabe as an African hero of the masses fighting against western imperialism. Sims et al. (2010: p. 11) maintain that EU-Africa Summit is a good example of this show of support, the Summit was scheduled to take place in Lisbon in 2003, but had to be postponed after several African Heads of State boycotted the event because Mugabe was not invited to attend. Moreover in 2007, Portugal pushed for an exemption from the travel ban on Mugabe in order to allow him to attend the Lisbon Summit that year (Sims et al., 2010: p. 12). One can therefore argue that the failure of the AU and SADC to isolate Mugabe led to the inefficacy of sanctions.

To evade the vilification and effects of the suspension from IFIs and the cut in financial aid from the west, Zimbabwe simply looked East and embarked on the "Look East Policy" from 2002. The policy saw Zimbabwe developing closer economic relations with Iran, Iraq, India, Malaysia, North Korea, China, Indonesia and Singapore. The role of China has been mostly detrimental to the efficacy of sanctions. This stems from the fact from the onset China together with Russia used its veto power in the SC to vote against UN's imposition of sanctions against Zimbabwe. This is due to the reason that Zimbabwe-China relations stretch back from Zimbabwe's struggle for colonial freedom. China served as an alternative trading partner to Zimbabwe whose role in Zimbabwe's economy was largely felt during the period under study. Dugger (2010: p. 14) assert that in 2008, China signed a US $\$ 42$ million loan to support Zimbabwe's farm mechanisation programme, and in 2009, Zimbabwe secured credit lines of US $\$ 950$ million to support infrastructure projects and to purchase.

Chinese policy of non interference has meant that Zimbabwe would continue to enjoy economic relations with China. China has made sanctions against Zimbabwe ineffective for the reason that it has offered Zimbabwe with a sanctions-busting mechanism owing to the funding it presumes with Zimbabwe. Chingono (2013: p. 311) stipulates that China is also not too strict in terms of requirements for democracy when it comes to funding presumably because its own democratic structures stand to question when juxtaposed to Western parameters. Nonetheless, the West has perceived the Look East policy move as a desultory, face-saving political gambit meted out in desperation by a power-hungry cluster of manic despots Chingono (2013: p. 312).

Equally important in this manner is how globalisation has rendered sanctions ineffective in the Zimbabwean scenario. This is because globalisation has made it impossible for the sanctions to work as they have given Zimbabwe with alternative trading partners. Globalisation and sanctions are two parallel mechanisms in which the former seeks to unite states and bringing them into a one world village whilst the latter seeks to isolate states. It is paramount to note that the imposed sanctions were imposed at a point in time when globalisation was at its zenith, connecting states by the erasing of borders and through fast communication and transport. Zimbabwe managed to thwart the travel bans, trade embargos and arms embargo. This is also explained by the phenomenon of interdependence which denotes that no state is an island hence states are always in need of each other for trade and regional and international cooperation.

It is significant to also assess whether sanctions were effective in reducing political violence and fraud in the 2008 elections. Despite the sanctions, the 2008 March elections were marred with political violence and political intimidation perpetrated by ZANU PF. Karimakwenda (2008) reiterated that reports of violence by the youth militia and war veterans intensified in Murehwa constituencies and violent campaign aimed at opposition activities had the code name "Operation Mavhotera Papi" (who did you vote for). What is more striking about the 2008 elections was the delay in the releasing of the election results. Ploch (2009: p. 22) maintains that in remarks to the SC on April 16, Ban expressed his deep concern with the delayed release of the electoral results, warning that "the credibility of the democratic process in Africa could be at stake. Zimbabwe's first harmonised elections resulted in ZANU PF losing to the MDC-T. As the MDC-T did not meet up the required majority votes to presidency, runoff elections were to be carried out again. However due to the heave of violence against the MDC supporters, the MDC withdrew from the elections citing fears of more torturing and killing of its supporters. The end result was a disputed runoff election which saw Mugabe coming up as President. The period after Mugabe's swearing in witnessed civil strife and brutality and calls for Mugabe's resignation. It is from this point that one can argue that sanctions failed to compel the behaviour of the ZANU PF officials to follow democratic norms as electoral violence and intimidation were still perpetrated and sponsored by the targeted.

Subsequently due to pressure from the international community the political parties were able to come to terms and entered into a power sharing government which came out as a result of mediation talks initiated by the South African former president, Thabo Mbeki. The birth of the GNU whose basis is enshrined from the Global Political Agreement (GPA) has been argued as a positive effect of the imposed sanctions. It is paramount for one to take into consideration that the GNU stabilised the economy with introduction of a multi currency system 
which saw the US dollar and the South African rand being adopted into the financial system. The GNU signalled an environment for potential foreign investment, which is substantiated by Zimbabwe's economy which accelerated by more than nine percent in 2010 to 2011 before it declining to $5 \%$ in 2012 .

A most credible positive element of the GNU was the implementation of a new constitution in 2013. This move showed political maturity of the political parties in the GNU and most importantly it served as a transition to democracy which was one of the principal objectives of the sanctioners. According to Hartwell (2013), during their addresses at the second all-stakeholders conference, Mugabe and Tsvangirai both called for "peace" and at the end of his speech Mugabe stated, "Violence is primitive and here I would like to speak to ZANU PF; Tsvangirai is your neighbour and to the MDC; Mugabe is your neighbour, let us shame our detractors, who think Zimbabweans cannot resolve their differences without resorting to violence". Indeed sanctions had at least succeeded into pressurizing the Mugabe regime to come to terms with other political parties and also castigating political violence. Likewise, the EU responded to this positive step taken by the signatory parties of the GPA by removing a wide range of measures targeted against government officials, the EU and the US were willing to accept any government that came out from a free and a fair election and subsequently normalise relations.

Having considered the affirmative nature of the GNU, it is also logical to examine the flaws and weaknesses within the GNU. In theory all parties were committed in gratifying the GPA but in practice saw the failure of the parties to fully execute the obligations of the GPA. A key feature of the GNU flaws was ZANU PF's manipulation and denial to implement the GPA resolutions. From the ZANU PF viewpoint, sanctions were the major unsettled raison d'être behind Zimbabwe's socio-economic problems. The ICG (2012: p. 1) states that ZANU PF argues that reform is contingent on the removal of sanctions and accuses the MDC wing led by Prime Minister Morgan Tsvangirai MDC-T of reneging on GPA commitments to facilitate this, the MDC-T argues it has no control over sanctions, and there would be a stronger basis for their removal if GPA violations ended, and ZANU PF did not block reforms. Yet again, sanctions served as a rationalisation for ZANU PF's gimmick.

The drafting of the new constitution has been one of the foremost developments undertaken by the GNU in the period under study. Before dismissing the constitution as triumph attained as a result of the sanctions, it is important to observe the grounds under which the constitution emanated from, who formulated the constitution and how. Only from this standpoint can the constitution be credited as a positive element of the GNU.

The constitutional outreach programme was launched in mid June 2013 which saw the Constitutional Select Committee (COPAC) teams being deployed to carry out meetings with the people to air out their views on the constitution. CISOMM (2010: p. 29) indicates that, of great concern were the numerous reports of intimidation and coercion of citizens, particularly in the rural areas, by the military, paramilitary and (mainly ZANU PF) party supporters, with reports of uniformed forces in Chegutu, Masvingo, Matebeleland North, Matabeleland South and Manicaland campaigning for the ZANU PF backed Kariba draft and threatening MDC supporters with assault. There is wide spread evidence that in a bid to silence citizens, ZANU PF launched Operation Chimumu (Operation Dumbness) where citizens were instructed to remain silent and allow a selected few to contribute during COPAC meetings, cases of intimidation by ZANU PF were mostly recorded in the Mashonaland Provinces (ibid). Cases of sponsored violence were also reported. In face of sanctions, ZANU PF still prolonged its human rights violations in particular the freedom of expression.

Equally important is the environment under which the formulation of the constitution was carried out. The setting of the holding of meetings regarding the constitution was restrictive due to the continuation of repressive laws - Information and Protection of Privacy Act (IPPA) and Public Order and Security Act (POSA). These laws inhibited people from fully partaking in constitution meeting. CISSOM (2010: p. 29) maintains that although reports surfaced of the suspension of POSSA and IPPA ahead of the constitutional outreach phase in June, the Government - through information and publicity Ministry Permanent Secretary, George Charamba and Minister of Constitutional and Parliamentary Affairs, Honourable Eric Matinhenga refuted these claims.

According to CISOMM (2010: p. 29), although the GPA clearly stipulates that "it is the fundamental right and duty of the Zimbabwean people to take a constitution by themselves and for themselves, political parties and concerns have dominated the constitution making process in Zimbabwe". In spite of the accepted perception that entails the role of political parties in the formulation of the constitution, the actions of these political parties were an indirect gesture against the right of the people to make their own constitution. The period of the formulation of the constitution witnessed the two MDC factions and ZANU PF forming committees at community level with the aim of communicating with the people regarding the formulation of the constitution. ZANU PF has been accused mostly of going in advance of COPAC constitution meetings in a bid to train societies on what to say on these meetings. Amid such allegations, both the MDC and ZANU PF have responded by justifying 
their stance on hinting citizens with what to say arguing that each political party is permitted to air out its perspectives on the constitution.

Lovemore Madhuku castigated the constitution owing to the undemocratic nature of the formulation of the constitution, Madhuku lamented "This is not a democratic and people driven constitution a democratic constitution must be people driven". This is a constitution being imposed on us by three political parties. No political party or group of political parties must be allowed to give the country a constitution. A constitution must come from the people (Langa, 2013). This citation embodies the reality that the constitution was not a people driven constitution but a mere replication of the interests of the three political parties in the GPA.

Scoones (2013) maintains that the 2013 elections saw ZANU-PF reportedly garnering two-thirds of the parliamentary seats and in which President Mugabe won $61 \%$ of the presidential vote, with Morgan Tsvangirai picking up 34\%. MDC-T has called the elections "a sham", "a farce", "null and void" and GNU education minister, David Coltart, argued that "Zimbabwe has been subjected to electoral fraud on a massive scale" (ibid). The official observers from SADC and the AU however reiterated that the elections had been free and fair. It is important to note that the 2013 elections were characterised with less political violence. This was probably due to the fast communication of prior election action activities on social networks, with the popular facebook character "Baba Jukwa" who was at the forefront of revealing top secrets and likely evil plans of the ZANU PF party. Nonetheless disputes arose on the process of elections. Scoones (2013) also articulates that the Zimbabwe Election Support Network (ZESN) argued that there were major problems with the process, including voters' roll discrepancies, intimidation, late opening of polling stations, slow pace of assisting aspiring voters in some urban polling station, high number of assisted voters recorded in rural areas, shortage of ballot papers in some wards, first time voters denied the chance to vote as they were not appearing in the voters' roll and their registration slips had missing ward details. The MDC-T contested the election results arguing that there were rigged and that facilitation of election rigging was assisted by an Israeli company named Nikuv. One can therefore reach to the point that the 2013 were characterised with new ZANU PF trickery which deviated from its traditional methods of winning elections such as political intimidation and violence to a more peaceful rigging method which was carefully planned. At this junctures, still sanctions were ineffective in at least pressurising the ZANU PF elite to conduct a free, fair and transparent election process.

Sanctions were meant to seize the corruption engineered by the ZANU PF officials, nonetheless, sanctions did not auger well for harnessing corrupt ZANU PF activities. Of notable importance is the controversy surrounding the Chiadzwa diamonds. Sims et al. (2010: p. 15) maintains that shortly after the discovery of diamonds in Chiadzwa, the military intervened to take control of the fields while subjecting artisanal miners and area residents to egregious human rights abuses. As a result, Zimbabwe was suspended from importing and exporting diamonds however, Mugabe and Minister of Mines Obert Mpofu threatened to sell the diamonds outside of the Kimberley Process Certification Scheme. Despite this restriction, the ZANU PF elite continued to benefit from the diamond field at the expense of the people. The diamond fields were estimated to be worth 1 billion to 1.7 billion. Coltart (2013) denotes that sanctions and restrictive measures have been used to cover up massive corruption in the diamond sector particularly the Chiadzwa diamonds. He further argued that in the cabinet whenever they tried to investigate diamond receipts these efforts were always met with the excuse that there was need for secrecy because of sanctions, that if there was a truly transparent process that there would be used by hostile western governments to stop the export of diamonds from Zimbabwe and in so doing have a dramatic effect negative effect on the gross domestic product and revenue flows to the treasury (ibid). One can contend that the secrecy was only meant to benefit the government officials and help them loot more diamonds without checks and balances.

POSA and IPPA were still used to curtail the freedom of association and freedom of expression. During the period under study journalists, opposition political activists and human rights defenders continued to be harassed and intimidated. CISSOM (2010: p. 33) indicates that, on 31 March 2010 a journalist by the name Stanley Gama was summoned to Harare Central police station where he was interrogated because of an article published in the Sunday Times Zimbabwe edition. The article outlined an alleged urban land acquisition scam and involved Minister of Local Government Ignatius Chombo and businessman Phillip Chiyangwa (ibid). The government continued to use its state controlled media mostly the ZBC and the Herald to launch offensive and abusive attacks on the opposition. This was marred with gleeful chants after every half an hour on ZBC in praise of ZANU PF. There still remained no hope of freeing the airwaves or either ensuring a fair coverage from all political parties by the Zimbabwe government. Notwithstanding these limitations to the efficacy of sanctions, it is worth to consider that some media reforms were also instituted, this include the licensing of News Day, Weekly Worker, Daily Gazette, Daily News and the Mail. 


\section{Humanitarian Exceptions}

This section tries to examine the humanitarian exceptions that were ensured by the sanctioners in a bid to avoid the negative impact of sanctions on the general populace. Sanctions can be only considered effective when humanitarian costs are ameliorated. It is important to examine how international human rights were honoured by the sanctioners during the period under study.

In a bid to make void of the likely negative effects of sanctions, the sanctioners took steps that would ensure that basic human rights enshrined in International Human Rights Law were not violated by the effects of sanctions. Article 25 (1) of the UDHR states that :

"Everyone has the right to a standard of living adequate for health and well being of himself and of his family, including food, clothing, housing and medical care and necessary social services and the right to food security in the event of unemployment, sickness, disability, widowhood, old age, or other lack of livelihood in circumstances beyond his control" (Universal Declaration of Rights). This quote embodies the basic rights that are entitled to every individual. It is also from this and other articles that the efficacy of sanctions imposed on Zimbabwe are deliberated from.

Chingono et al. (2013: p. 312) maintain that Karel de Gutch the EU Commissioner for aid stated in 2008 that between 2002 and 2009, around 600 million Euros had gone to humanitarian aid and also 90 million Euros were also invested in Zimbabwe in 2009. The US has argued that ZIDERA was only meant to suspend future lending from International Institutions, this was for the raison d'être that Zimbabwe was not able to pay back its arrears, this however exempted humanitarian aid. According to Hudson-Dean who is the spokesperson of the US embassy in Harare, ZDERA provisions contained in subsequent appropriations acts, restrict the ability of the US to cast its vote in support of new assistance to Zimbabwe from international financial institutions (IFI's), except for programs that meet basic human needs or promote democracy. ZDERA was therefore not an impediment to Zimbabwe's reengagement with the IFIs. Hudson-Dean further argues that the US provided over $\$ 300$ million in 2009 and over \$200 million in 2010 for humanitarian, food, health, and democracy and governance assistance to Zimbabwe. The US continued in 2011 the humanitarian assistance provision including also the amount channelled for the fight against HIV and AIDS worth a total of $\$ 57.5$ million. It is from this standpoint that makes it clear that the sanctions were targeted and not meant for the whole nation.

Gono (2007: p. 5), however, argues that humanitarian assistance was short-term, and did not directly contribute to long term economic development and poverty reduction. This is coupled with the fact that humanitarian aid only focused on human rights, HIV AIDS and social issues. Sanctions also resulted in other donors freezing development assistance, or relocating their offices to other neighbouring countries which had a negative impact on the ordinary people. Gono (2007: p. 5) further pronounces that DANIDA and the Canadian International Development Agency (CIDA) pulled out of Zimbabwe in 2001 and 2003, respectively, terminating all projects in progress and retrenching their employees.

Critics have criticised the sanctions against Zimbabwe as their negative effects were largely felt by the innocent civilians despite them being targeted against few individuals. Mbanje \& Mahuku (2011: p. 4) reiterate that the late 20st Century saw Zimbabwe being dubbed the "Bread basket" of the Southern African region due to its huge agricultural production which resulted in its exportation of surplus grain to its fellow member states of the SADCC (now SADC). From 2000 up to 2009, Zimbabwe's food production declined heavily due to lack of funding to the recently resettled black farmers by the EU as well as ceaseless droughts experienced in the entire Southern African region (ibid). The failure to access funds from the IFI affected Zimbabwe's food security. This is due to the fact that the accomplishments of any land reform programme lies solely on the support new farmers are given in the form of sufficient agricultural inputs. Subsequently the country faced immense food shortages. Basic commodities such as maize, cooking oil, salt, sugar became scarce. The ordinary citizens suffered from starvation. This is in clear violation of international law. This is confirmed by the UN General Assembly in December 1997 voted that starvation of civilians is unlawful. Moreover, the International Conference on Nutrition, World Declaration on Nutrition, Food and Agriculture Organization/World Health Organization in 1992 declared: "We recognize that access to nutritionally adequate and safe food is a right of each individual. We affirm that food must not be used as a tool of political pressure (ibid)".

Equally imperative were the water challenges that were faced by the ordinary citizens. Civilians were left with no option but to resort to unprotected water sources such as open wells and rivers. Hove (2012: p. 78) asserts that such a development led to loss of lives due to the outbreak of cholera whose epi-centre was Budiriro a high 
density residential place in Harare. Hove (2009: p. 78) reported that the outbreak of a cholera epidemic took a toll across the country with 191,164 reported cases and 4047 reported deaths for the period 15 August 2008 to 17 March 2009. Ploch (2009: p. 17) articulates that in Zimbabwe, the reported case fatality rate (CFR) reached almost $6 \%$ at its peak in January 2009, much higher than the normal 1\% CFR rate for cholera cases globally. The causes of cholera were also due to the bursting of sewages and contaminated water from the city council. In other areas water was available but the responsible authorities for water did not have enough chemicals to make the water safe for human consumption. The sanctions made it problematic to acquire water chemicals hence affecting the vulnerable other than the targeted. In response to the humanitarian crisis, Ploch (2009: p. 25) articulates that the US government provided over $\$ 7.3$ million in FY2009 specifically to address the cholera outbreak, in addition to $\$ 8.5$ million for other water and sanitation programs.

Richardson (2007: p. 6) observes that from 2002 onwards, following the partial withdrawal of EU official aid to the health sector, there was a recorded diminution of essential drugs in $73 \%$ of Zimbabwe's health facilities. The government also failed to sustain public health institutions such as clinics and hospitals. Coupled with this was the massive brain drain of nurses and doctors who flocked to neighbouring countries for greener pastures.

Mbanje \& Mahuku (2011: p. 8) assert that the decrease in aid from 2000 weakened the EU-Zimbabwe relations, the government failed to give teachers adequate salaries, as a result teachers flocked mostly to neighbouring countries such as South Africa, Botswana and Namibia. European Commission (2006: p. 14) conveyed that in 2006 about 4500 Zimbabwean teachers refrained from their jobs immensely affecting the quality of education in Zimbabwe. The result was the sprouting of informal institutions known as colleges whose learning structures were churches and residential homes. Hove (2012: p. 80) alludes that Washington Mbizvo, Higher and Tertiary Education Permanent Secretary acknowledged the emergency of informal schools when he commented that, "There are 524 registered independent training colleges in the country but thousands had sprouted over the years". The standard of education had derailed. Equally important were the water shortages that affected learning in schools and colleges. Several universities closed in 2008 when the crisis was at its peak. Sanctions had clearly led to the violation of the right to education enshrined in UDHR Article 26 (1) which states that: "everyone has the right to education..."

From this standpoint one is safe to argue that without doubt the sanctions had gross basic human rights violations. The ordinary citizens suffered most. The food shortage, the lack of clean water, denial of basic education as a result of the sanctions makes it clear that they were not effective as they did not have any effect on the targeted. The crisis was due to the country's incapability to access funds from the IFIs.

\section{Conclusion and Recommendations}

While there seems to be a disparity on the nature of sanctions between the sanctioners and the MDC on one hand and ZANU PF on the other hand, the fact that sanctions have a direct effect on the economy and the civilians deems them untargeted sanctions. In a country like Zimbabwe where most of the businesses that sustain the nation are owned by the government officials, the targeted sanctions are most likely to have an impact on the ordinary citizen. It could be that the impact of sanctions on the ordinary citizens was by accident but this inherently made the sanctions ineffective. The research has also revealed that it is certain that there exists a breach of peace due to the lack of democratic norms and violations of human rights perpetrated by the Mugabe regime, despite the likeable double standards of the sanctioners. The validity of the legality of sanctions is justified therefore.

The research has demonstrated that sanctions are not an effective law enforcement tool of international law. The targeted individuals' behaviour deemed impossible to compel. This was due to the incomprehensive nature of sanctions imposed on the targeted. The fact that the West was for the sanctions and the East against sanctions made the travel banned and arms embargoes useless. The research has clarified the reality that the sanctioned targets can always find ways to circumvent the restrictions by connecting with friendly nations. Moreover, globalisation has rendered the isolation of Zimbabwe unfeasible due to the interconnectedness of states and the principle of interdependence which lead to the continuing of trade relations of Zimbabwe and other states. The international sympathy received by the targeted from the international fora contributed to the failure of sanctions to compel the targeted's behaviour.

The sanctions did succeed in applying pressure to the targets; this was witnessed by the formation of the GNU and the inherent drafting of the constitution. Despite the fact that the Mugabe regime had vowed not to negotiate 
with opposition parties, because of the pressure of sanctions, the regime succumbed to it, making it clear that sanctions were effective in exerting pressure on the targeted. The formulation of the constitution questions also the efficacy of sanctions in the compelling the behaviour of the targets. Moreover, electoral fraud, intimidation and political violence, denial of freedom of expression and association remained unchanged throughout the period under study with exception of a few occasions after the formation of the GNU. Nonetheless, sanctions were used as a scapegoat for ZANU PF's blunders in the past that led to an economic crisis, failure to meet GPA obligations and corrupt activities particularly in the Chiadzwa diamond fields. Sanctions were ineffective in that they did not meet up the desired objectives of the sanctioners. While the underlying principle for the targeted sanctions against ZANU PF was to coerce it to reform, the sanctions realised the contradictory, owing to the impression it gave that ZANU PF was hardening its stance. Moreover, sanctions hurt the innocent civilians harshly. Using sanctions as a law enforcement tool is thus not feasible as it ends up violating the fundamentals of international law, in particular International Human Rights Law.

The predicament does not lie in the imposition of sanctions but in the effects they cause. The effectiveness of sanctions should be improved, by reducing the negative effects of sanctions. This paper concludes that sanctions can harden the targets and at the same time affect negatively the untargeted mostly and thus can be an ineffective enforcement tool for international law.

This study recommends that the government of Zimbabwe adopts democratic norms and principles, diverge from human rights abuses and corruption. It is no doubt that the incompetence of the government of Zimbabwe plays a part in bringing down the economy of Zimbabwe. It is blind to blame the sanctions entirely for Zimbabwe's crisis. To the sanctioners, the study recommends the lifting of sanctions as they have proved to be unnecessary as they hurt the innocent and on the other hand tighten the grip of ZANU PF.

\section{References}

(2005). Government/ZANU PF Loses Z\$800 Million Dollars to Sanctions. Zimbabwe Independent, 12 August.

(2009). Who's Land? The Economist, March 5. www.economist.com/node/13240812

(2013). Abstracts of Presentations. Symposium on Unilateral Sanctions and International Law: Views on Legitimacy and Consequences. T.M.C. Asser Institute, The Hague, 11 July 2013.

Abadi, G. K. (n.d). Unilateral Sanctions against Iran and International Law.

Barker, J. C. (Year). The Enforcement of International Law. www.eolss.net/eolsssamplechapters/c14e1-44-01/e1-44-01-txt-02aspx

Beckman, R., \& Butte, D. (n.d). Introduction to International Law.

Bengtsson, M. (2002). Economic Sanctions Go Smart: A Human Rights Perspective.

Charter of the United Nations https://treaties.un.org/doc/publication/ctc/uncharter.pdf

Chingono, H. (2010). Zimbabwe Sanctions: An Analysis of the "Lingo" Guiding the Perceptions of the Sanctioners and the Sanctionees. African Journal of Political Science and International Relations, 4.

Chingono, H., Hove, M., \& Danda, J. S. (2013). Sanctions Effectiveness in a Globalised Era. International Journal of Humanities and Social Science, 3.

Chogugudza, C. (2009). Long Story of Zim Sanctions. The Financial Gazette, 10-16 September.

Civil Society Monitoring Mechanism (CISOMM) (2010). Six Month Shadow Report on the Performance of the Inclusive Government of Zimbabwe.

Coltart, D. (2013). Sanctions Shielding Zanu PF. Southern Eye, 23 September.

Council of the European Union. 15 February 2002, 6284/02.

Elliott, A. K., \& Hufbauer, C. G. (2002). The Concise Encyclopaedia of Economic Sanctions. http://www.econlib.org/library/Enc/Sanctions.html

Eriksson, M. (2007). Targeting the Leadership of Zimbabwe: A Path to Democracy and Normalisation. Upssula University Department of Peace and Conflict Research.

EU Renews Targeted Sanctions against Mugabe (2013). www.newzimbabwe.com/pages/sanctions20.12297.html

European Commission (2008). Restrictive Measures.

European Commission-Zimbabwe (2006). Joint Annual Report 2006; EC-Zimbabwe.

Full Text: Mugabe's Speech to the $68^{\text {th }}$ Session of UN General Assembly. 26 September 2013. http://www.newzimbabwe.com/news-12465-Full+text+Mugabes+2013+UN+speech/news.aspx 
Gono, G. (2007). The Impact of Sanctions against Zimbabwe. http://rbz.co.zw/pdfs/farm_mech/sanctions.pdf

Grebe, J. (2010). And They Are Still Targeting: Assessing the Effectiveness of Targeted Sanctions against Zimbabwe. Africa Spectrum, 45, 3-29.

Hartwell, L. (2013). Reflecting on Positive Zimbabwe GNU Moments. The Zimbabwe Independent, 7 November.

Hove, M. (2012). The Debates and Impact of Sanctions: The Zimbabwean Experience. International Journal of Business and Social Science, 3.

Hovi, J., Huseby, R., \& Sprinz, F. D. (2005). When Do (Imposed) Economic Sanctions Work? World Politics, 57, $479-499$. http://dx.doi.org/10.1353/wp.2006.0011

Hudson-Dean, S. The Truth about United States Policy towards Zimbabwe. http://harare.usembassy.gov/policy_explain.html

Hughes, K. (2007). Operation "Drive out the Trash": The Case for Imposing Targeted United Nations Sanctions against Zimbabwean. Fordham Law Review, 76.

Johnson-Thomas, B., \& Danssaert, P. (2009). Zimbabwe-Arms and Corruption: Fuelling Human Rights Abuses. www.thezimbabwean.co/human-rights-abuses-.html

Kôchler, H. (1992). The United Nations Sanctions Policy and International Law. Turkish Yearbook, Volume XXII.

Lektzian, D., \& Souva, M. (2007). An Institutional Theory of Sanctions Onset and Success. Journal of Conflict Resolution, 51.

Madhuku, L. (2013). Vote No to Draft Constitution. News Day, 15 March.

Masaka, D. (2012). Paradoxes in the "Sanctions Discourse" in Zimbabwe: A Critical Reflection. African Study Monographs, 33.

Mashingaidze, M. T. (2006). The Zimbabwe Entrapment: An Analysis of the Nexus between Domestic and Foreign Policies in a "Collapsing" Militant State, 1990s-2006.

Mbanje, C. B. B., \& Mahuku, N. D. (2011). European Union Sanctions and Their Impacts on Zimbabwe 2002-2011: Finding Alternative Means to Survive. Sacha Journal of Policy and Strategic Studies, 1.

Ndakaripa (n.d). Sanctions or Targeted Restrictive Measures? The United States and European Union "Sanctions" on Zimbabwe, 2001 to 2010. Harare: Department of History, University of Zimbabwe.

Nyamutata, C. (2013). Zanu PF Economic with the Truth. Daily News, 22 October.

Parliamentary Debates (2006). The Senate, Zimbabwe, Official Report. Unrevised, Volume 16, No. 3, Wednesday, 9th August.

Pasirayi, P. (2009). Deliver Democracy to Remove Sanctions. The Zimbabwe Independent, April 2.

Paul, A. J., \& Akhtar, S. (1998). Sanctions: An Analysis. Global Policy Forum, August 1998. www.globalpolicy.org/component/content/article/202/41612.html

Ploch, L. (2009). Zimbabwe: The Power Sharing Agreement and Implications for US Policy. Congressional Research Service, October 27.

Richardson, P. (2007). Zimbabwe's Health Dilemma. Sunday Times, August 19.

Sanctions and International Law (2013). www.scn.org/wwfor/iraqlaw.html

Segall, A. (1999). Economic Sanctions: Legal and Policy Constraints. 31 December Article, International Review of the Red Cross, No. 836. www.icrc.org/eng/resources/documents/misc/57ja73.htm

Shrener, C. (n.d). Sources of International Law: Scope and Application. The Emirates Centre for Strategic Studies and Research.

Sims, B., Masamvu, S., \& Mirell, H. (2010). Restrictive Measures and Zimbabwe: Political Implications, Economic Impact and a Way Forward. IDASA, November.

Smith, S. (2006). Sanctions: Diplomatic Tool, or Warfare by Other Means? www.beyondintractibility.org/essay/sanctions Accessed 14 March 2014

Smith-Hohn, J. (2010). Zimbabwe: Are Targeted Sanctions Smart Enough? On the Efficacy of International Restrictive measures. ISS Situation Report, June 4.

Tererai, K. (2008). ZANU PF Launches “Operation Mavhotera papi” to Punish Opposition. April 14. http://www.zimbabwesituation.com/old/apr15a_2008.html

Thucydides, (1972). History of the Peloponnesian War. New York: Penguin Book

Trocan, M. L. (2009). Sanctions in Public International Law. Days of Law: The Conference Proceedings, Brno: Masaryk University.

Tungwarara, O. (2011). Sanctions: In Aid of Transition or an Obstacle to Democracy. In R. Lee (Ed.), Zimbabwe at the Crossroads. Open Space, Open Society Initiative for Southern Africa. 
Zim Farm Invasions Keep Investors Away (2010). Mail and Guardian, January 10.

Zimbabwe 2013 Elections More Confusing, More Uncertainty. africanarguments.org/2013/08/05/zimbabwe's-elections-2013-more-uncertainity-ny-ian-scoones/ 